\title{
球形のイオン交換樹脂からの計数率 ${ }^{\dagger}$ \\ ${ }^{32} \mathrm{P}$ が樹脂中に均一に分布する場合
}

田口洋治, 酒井信之

新潟大学工学部化学工学科

長岡市学校町 1 丁目

1973年 7 月 6 日受理

\section{1. 緒 言}

イオン交換樹脂中への拡散問題を取り扱ら場合に"1 放射性同位元素で置換されたイオンの挙動から考察す る例が多く見られる。ことに同位体交換反応を利用し た自己拡散の問題では, 放射性同位元素は有力な武器 となっている。この場合, 自己吸収の補正を避ける意 味から溶液側の濃度変化を追跡するのがつねで，樹脂 側から直接定量化する例は少ない。

樹脂側から吸着量をあえて定量化する場合には， $\gamma$ 線を放出する形の陽イオンを使い定量するほうが容易 である。その理由は， $\gamma$ 線源の場合の吸収はイオン交 換樹脂の密度が小さいこと，イオン交換樹脂の径がた かだか 1 〜 $2 \mathrm{~mm}$ 程度であることからほとんど無視し らるからである。これに反し，陰イオンを扱ら場合に はイオンの中に $\beta$ 線源となる核種がはいる場合が多い ので，イオン交換樹脂による吸収の補正が必要であ る。それゆえ，この現象は陰イオンの取扱いを敬遠さ

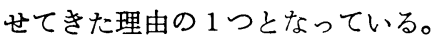

著者らはあえて， $\beta$ 線を伴う陰イオンがイオン交換 樹脂に取り込まれる場合の吸収を考光，樹脂表面での 放射能強度の算出を試みた。すなわち，樹脂の形状を 球形々考光，平均的な相対強度を定義することにより 球面での計数率を推定した。結果的には $\gamma$ 線の場合を も包含する一般的なものとなった。理論式の信頼性を 判定するために， ${ }^{32} \mathrm{PO}_{4}^{3-}$ を使い実験的に確かめたと ころ，満足すべき結果を得たので報告する。

\section{2. 理 論}

$2 \cdot 1$ 球内の 1 点からの相対強度の定義

厚さ計などの原理にもなっているごとく，入射放射 線の強度を $I_{0}$ とし，厚さ $x$ の物体を透過したのちの
放射線の強度を $I$ とすれば，放射線の吸収による減衰 は近似的に,

$$
I / I_{0}=e^{-\mu x}
$$

で表わせる。 $\mu$ は吸収係数である。

そこで，球の場合に(1)式を適用するために， $x$ に相 当する距離を決めておく必要がある。イオン交換樹脂 のみならず，一般汇球形の固体粒子内の任意の 1 点を Fig.1 (a)の $\mathrm{O}^{\prime}$ のごとく考光, $\mathrm{OO}^{\prime}$ 軸を $y$ 軸に選び, $\mathrm{OO}^{\prime}=r$, 球の半径を $R$ とする。(1)式の $x$ に相当する 距離 $l$ は $\overline{\mathrm{O}^{\prime} \mathrm{P}}$ となり， $R-r$ から $R+r$ まで変化し, $r, \theta, \varphi$ の関係として表示しうる。したがって球内の

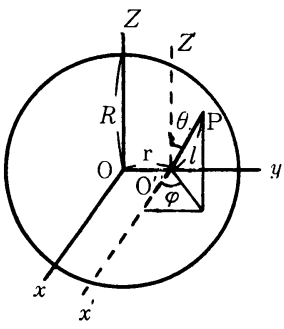

(a) sphere

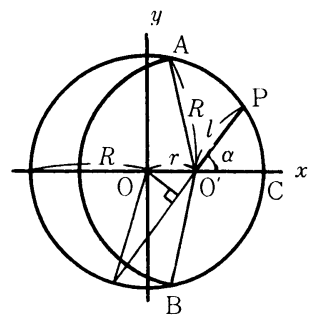

(b) disk
Fig. 1 Distances in a sphere and a disk.

任意の 1 点 $\mathrm{O}^{\prime}$ からの相対強度 $\langle\exp (-\mu l)\rangle_{a v}$ を次 式のごとく定義する。

$$
\left\langle\exp (-\mu l)>_{a v}=\frac{\int_{0}^{\pi} \int_{0}^{2 \pi} \exp \{-\mu l(r, \theta, \varphi)\} d \theta d \varphi}{\int_{0}^{\pi} \int_{0}^{2 \pi} d \theta d \varphi}\right.
$$

$\dagger$ Counting Rate from a Spherical Ion Exchange Resin Containing ${ }^{32} \mathrm{P}$ Homogeneously. Yoji TAGUCHI and Nobuyuki SAKaI: Department of Chemical Engineering, Faculty of Engineering, Niigata University, Gakkocho, Nagaoka. 


$$
\begin{aligned}
= & \frac{1}{2 \pi^{2}} \int_{0}^{\pi} \int_{0}^{2 \pi} \\
& \exp \{-\mu l(r, \theta, \varphi)\} d \theta d \varphi
\end{aligned}
$$

$l(r, \theta, \varphi)$ を決めるためにまず Fig.1(b) 亿示す平面 の場合を考え, 任意の 1 点 $\mathrm{O}^{\prime}$ を通るように $x$ 軸を設 定する。球の場合と同じく， $\mathrm{O}^{\prime}(r, 0)$ から円周まで の距離は $R-r$ から $R+r$ まで変化し次式で表わせ る。すなわち,

$$
\mathrm{O}^{\prime} \mathrm{P}=l(r, \alpha)=\sqrt{R^{2}-r^{2} \sin ^{2} \alpha}-r \cos \alpha
$$

上式で $r \cos \alpha$ の符号は正，負いずれを取っても良 い。つぎに, 平面での $\mathrm{OO}^{\prime}$ と球座標の $\mathrm{OO}^{\prime}$ の軸と を重ね，方向余弦を考兵ると， $\cos \alpha=\sin \theta \cdot \sin \varphi$ の 関係が成り立つので，(4)式は球の場合に次式のごとく 変形される。

$$
\begin{gathered}
l(r, \theta, \varphi)=\sqrt{R^{2}-r^{2}\left(1-\sin ^{2} \theta \cdot \sin ^{2} \varphi\right)} \\
-r \sin \theta \cdot \sin \varphi
\end{gathered}
$$

(5)式を(3)式に入れ， $\theta, \varphi$ について積分すればよいが， 解析的に解けないので数值積分に任ねる。ただし， $r=0$ の場合に(3)式は $\exp (-\mu R)$ となる。Simpson の近似により(3)式の二重積分を実行した結果の一例を Fig. 2 に示す。粒子内の任意 1 点（原点Oより $r$ だけ 離れた点）から球面までの平均的な相対強度の関係を 表わす。

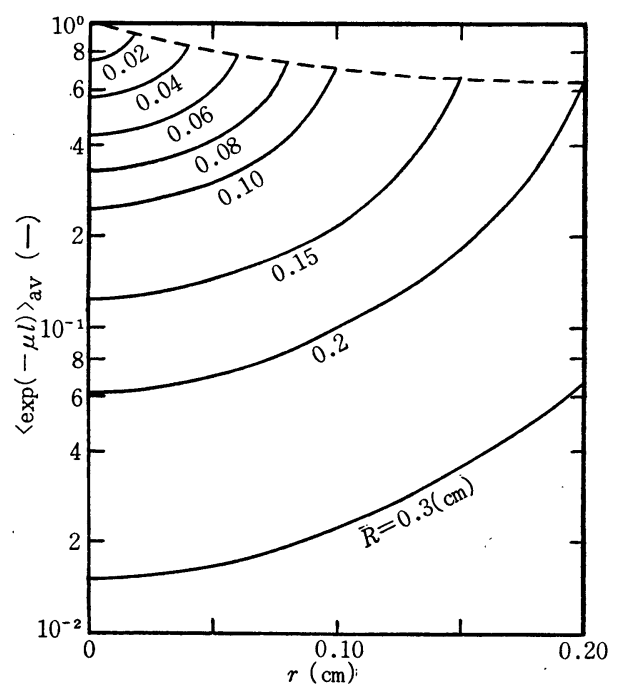

Fig. 2 Average relative intensity from an arbitrary point in a sphere.

\section{$2 \cdot 2$ 球面上での計数率}

イオン交換樹脂に $\beta$ 線放出の核種が取り込まれる場 合も含め, 一般に標識化合物が粒子内に均一に分布す
る場合，粒子表面に和ける $\beta$ 放出率 $N$ を考えると，

$$
N=\int_{0}^{R} 4 \pi r^{2} \lambda q<\exp (-\mu l)>_{a v} d r(\mathrm{dps})
$$

を得る。 $q$ は単位体積中に取り込まれる核種の個数で あり，入は崩壊定数である。また，計数効率 $f$ を入れ ると,

$$
N=4 \pi \cdot 60 f \lambda \int_{0}^{R} q r^{2}\left\langle e^{-\mu l}\right\rangle_{a v} d r(\mathrm{cpm})
$$

したがって $q$ を実験的に決めれば，(7)式により計数率 を算出できる。さらに一般的に, 球の $r$ 方向に分布が 存在する場合には, $q$ を $r$ 関数 $q(r)$ として(7)式に 与えれば(7)式はそのまま使える。

\section{3. 実験による検討}

(7)式の信頼性を実測される計数値から検討するため にまず $q$ の值を実験的に求めた。陰イオン交換樹脂 には Amberlite IRA-425を使い, 吸着される ${ }^{32} \mathrm{P}$ は $\mathrm{PO}_{4}^{3-}\left(\mathrm{K}_{2} \mathrm{HPO}_{4}\right.$ を carrier として加えた）の陰イオ ンの形で用いた。樹脂側で $\mathrm{OH}^{-}$から $\mathrm{PO}_{4}^{3-}$ の交換 反応を $300 \mathrm{ml}$ のフラスコ中で行なわせた。樹脂に吸着 されるイオンの個数を求めるのに, 溶液濃度の減少量 と樹脂の個数打よびその平均径より算出した。濃度変 化を比色分析 ${ }^{5)}$ と比放射能の測定より求めて $q$ を算出 した。

\section{4. 実験結果}

実験值とその計算結果の一例を Table 1 に示す。 $\bar{R}, \bar{R}^{\prime}$ は樹脂の膨潤時と乾燥時に打ける平均半径を表 わす。仕込液濃度 $C_{0}$, イオン交換 終了時の濃度 $C_{t}$ はそれぞれ 5 回の比色分析の平均値である。それらよ

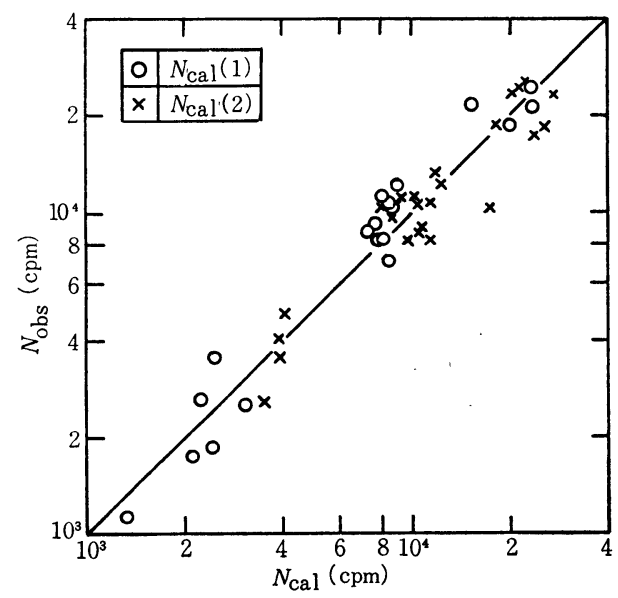

Fig. 3 Comparison of calculated and observed values. 
Table 1 Experimental and calculated values

\begin{tabular}{c|c|c|c|c|c|c}
\hline $\begin{array}{c}\bar{R}^{\prime} \\
(\mathrm{cm})\end{array}$ & $\begin{array}{c}\bar{R} \\
(\mathrm{~cm})\end{array}$ & $\begin{array}{c}C_{0}-C_{t} \\
(\mathrm{ppm})\end{array}$ & $\begin{array}{c}N_{0}-N_{t} \\
(\mathrm{cpm} / \mathrm{ml})\end{array}$ & $\begin{array}{c}N_{\text {cal(1) }} \\
(\mathrm{cpm})\end{array}$ & $\begin{array}{c}N_{\text {cal (2) }} \\
(\mathrm{cpm})\end{array}$ & $\begin{array}{c}N_{\text {obs }} \\
(\mathrm{cpm})\end{array}$ \\
\hline 0.06461 & 0.05195 & 0.5036 & 949 & 2235 & 3518 & 3111 \\
0.07063 & 0.05552 & 1.1564 & 2644 & 7891 & 9766 & 9739 \\
0.07260 & 0.05730 & 0.4558 & 741 & 8717 & 8266 & 12347 \\
0.07557 & 0.05097 & 0.8745 & 3027 & 9190 & 13129 & 14354 \\
0.06961 & 0.05863 & 1.1281 & 3325 & 20000 & 18351 & 22532 \\
0.07033 & 0.05802 & - & 6119 & - & 27729 & 27360 \\
0.07478 & 0.05997 & 1.3223 & 3864 & 23222 & 21084 & 29223 \\
\hline
\end{tabular}

り $q$ を求め(7)式を使い半減期の補正を施し， $N_{\text {cal(1) }}$ 求めた。また, $N_{0}, N_{t}$ は吸着前後の溶液の比放能で, $N_{0}-N_{\iota}$ より $q$ を算出し, さらに(7)式を使って $N_{\text {cal(2) }}$ を求めた。 $N_{\mathrm{obs}}$ は $4 \pi$ ガスフローカウンターにより 計数 ${ }^{3)}{ }^{4}$ ᄂ) して得たもので，樹脂 1 個あたりの平均的な 計数率である。

つぎに $N_{\text {cal }}$ を横軸て， $N_{\text {obs }}$ を綎軸にプロットす ることにより Fig. 3 を得た。

\section{5. 考察}

Fig. 3 で多少バラッキが見られるが，平均的な相 対強度より求めた(7)式は十分粒子表面での $\beta$ 放出率を 表わしているものと思われる。バラッキの原因は主と して吸収曲線からくる誤差で，Fig. 4 に示すごとく， 計算に採用した関係 ${ }^{2)}$ (Fig. 4 では実線) は実測した

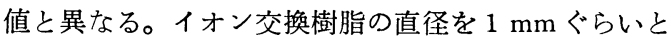
仮定すれば，アルミニウムの厚さにして0.17g/ $\mathrm{cm}^{2}$ と

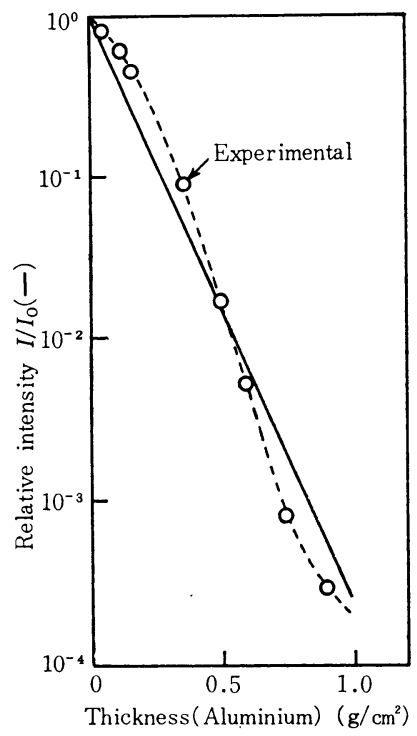

Fig. 4 Absorption curves.
なり，今回の実験範囲で $N_{\text {cal }}$ をやや増加させる。し たがってこれを解決するにはより正確な吸収曲線のカ ーブを数式化して，(1)式を変形する必要がある。

$N_{\text {cal(2) }}$ 算出時に央験的に与えねばならない $q$, す なわち $N_{0}, N_{t}$ の自己吸収による誤差はほとんど無視 しうる程度であった。また, carrier 中の ${ }^{40} \mathrm{~K}$ の計 数率への影響はほとんどなかった。

Fig. 2 に図示した相対強度は $r$ が大きくなるにし たがい大きくなっている。この理由は半径 $R$ の球内の 1 点が中心より球面に移行するにしたがい，同一半径 $R$ で描いた円と球面で交わる円の $\mathrm{O}^{\prime}$ に対してはる立 体角が $2 \pi$ より大きくなり， $R-r$ 側の寄与が大きく なり相対強度が大きくなる。すなわち，Fig. 1 (b) の 平板の場合でいい換えると, $\angle \mathrm{AO}^{\prime} \mathrm{C}+\angle \mathrm{CO}^{\prime} \mathrm{B} \geqq \pi$ と なり，相対強度を大きくしている。

分布が均一になっているかどうかについては, XMA によって観察したところほぼ一様な分布になっ ていることを確認した。また，樹脂は球形に近く，実 験の対象としてふさわしいことも確認した。

\section{6. 結 語}

粒子内に放射性同位元素が均一に分布する場合に， 球面上で観測される計数率を，粒子内の任意の 1 点か ら球面までの相対強度を定義することにより(7)式で与 えた。そこでイオン交換樹脂を使い実験的に確かめた ところ，ほぼ満足すべき結果を得た。

吸収曲線のより確かなデーダに基づけば， $\beta$ 線放出 の核種の場合も含め, $\gamma$ 線放出の核種が粒子内に存在 する場合にも本計算手法を利用しらる。粒子内に分布 が存在する場合には，qをrの関数として与えれば(7) 式はそのまま使える。

実験にご協力下さいました横田優君（現在石川島幡 磨重工KK）扣よび本学部学生江川一雄, 宮川真, 望 
月修，辻隆諸君に厚く感謝いたします。

\section{文献}

1) Hering, B. and Bliss, H.: A.I.Ch.E.J., 9, 495 (1963)

2）日本アイソトープ協会編：アイソトープ便覧， p.75，丸善株式会社 (1970)

3) Pate, B. D. and Yaffe: Can. J. Chem., 33,
610, 929 (1955)

4) Seliger, H. H. and Carvallo, L.: Natl. Bur. Stad. J. Research, 47, 41 (1951)

5) Snell, F.D. and Snell, C. T.: Colorimetric Methods of Analysis, 3rd Ed., vol. II, p. 660 71, D. Van Nostrand Co., Inc., Prinston, New Jersey (1967) 